\title{
KARAKTERISASI DAN AKTIVITAS ANTIOKSIDAN SERAT PANGAN DARI TEPUNG BIJI ALPUKAT (Persea americana Mill)
}

\author{
Yosep Rudol Parinding ${ }^{1}$, Edi Suryanto ${ }^{1}$, Lidya Irma Momuat ${ }^{1}$ \\ ${ }^{1}$ Program Studi Kimia, Fakultas Matematika dan Ilmu Pengetahuan Alam Universitas Sam Ratulangi \\ Manado \\ Email: yoseprudolparinding1@gmail.com
}

\begin{abstract}
ABSTRAK
Penelitian ini bertujuan untuk mengetahui karakteristik dan aktivitas antioksidan serat pangan dari tepung biji alpukat yang diekstraksi menggunakan gelombang ultrasonik dengan pelarut etanol dan aquades. Penelitian ini terdiri dari 3 tahap yaitu mikronisasi, ekstraksi dan karakterisasi. Parameter yang digunakan adalah komposisi proksimat, serat pangan, kandungan hemiselulosa, selulosa, lignin, karakteristik gugus fungsi, aktivitas antioksidan dan kapasitas penangkal nitrit. Hasil karakterisasi secara fisik tepung biji alpukat yang diekstraksi dengan etanol (EBA) dan aquades (ABA) dengan Fourier Transform Infra Red (FTIR) tidak mengalami perubahan mendasar pada komponen utama setelah proses penggilingan dan ekstraksi secara sonikasi. Hasil karakterisasi secara kimia menunjukkan EBA mengandung komposisi kimia seperti air $(7,94 \%)$, abu $(1,87 \%)$, protein $(5,32 \%)$, lemak $(0,47 \%)$ serat pangan tak larut $(18,40 \%)$, serat pangan larut $(0,24 \%)$, serat pangan total $(18,64 \%)$, hemiselulosa $(42,69 \%)$, selulosa $(4,35 \%)$ dan lignin $(15,14 \%)$. ABA mengandung air $(8,84 \%)$, abu $(1,64 \%)$, protein $(5,20 \%)$, lemak $(0,79 \%)$ serat pangan tak larut $(17,79 \%)$, serat pangan larut $(0,37 \%)$, serat pangan total $(18,16 \%)$, hemiselulosa $(37,71 \%)$, selulosa $(5,47 \%)$ dan lignin $(20,08 \%)$. Hasil pengujian aktivitas antioksidan menunjukkan bahwa ekstrak fenolik terikat EBA $(95,93 \%)$ tertinggi diikuti oleh ekstrak fenolik terikat ABA $(92,22 \%)$, ekstrak fenolik bebas EBA $(85,04 \%)$ dan ekstrak fenolik bebas EBA $(77,51 \%)$.
\end{abstract}

Kata kunci: Karakterisasi, antioksidan, serat pangan, tepung biji alpukat

\section{ABSTRACT}

The objectives of this research were to determine the characteristics and antioxidant activity of dietary fiber from avocado seed powder extracted using ultrasonic waves with ethanol and aquades as solvents. This research consisted of 3 stages, namely micronization, extraction and characterization. The parameters used were proximate composition, dietary fiber, hemicellulose content, cellulose, lignin, functional group characteristics, antioxidant activity and nitrite-scavenging capacity. The results of physical characterization of avocado seed flour extracted with ethanol (EBA) and distilled water (ABA) with Fourier Transform Infra Red (FTIR) did not experience a fundamental change in the main components after the milling and extraction process by sonication. The results of chemical characterization showed that EBA contained chemical compositions such as water $(7,94 \%)$, ash $(1,87 \%)$, protein $(5,32 \%)$, fat $(0,47 \%)$ insoluble dietary fiber $(18,40 \%)$, soluble dietary fiber $(0,24 \%)$, total dietary fiber $(18,64 \%)$, hemicellulose $(42,69 \%)$, cellulose $(4,35 \%)$ and lignin (15,14\%). ABA contains water $(8,84 \%)$, ash $(1,64 \%)$, protein $(5,20 \%)$, fat $(0,79 \%)$ insoluble dietary fiber $(17,79 \%)$, soluble dietary fiber $(0,37 \%)$, total dietary fiber $(18,16 \%)$, hemicellulose $(37,71 \%)$, cellulose $(5,47 \%)$ and lignin $(20,08 \%)$. The results of the antioxidant activity test showed that EBA had the highest bound phenolic extract $(95,93 \%)$ followed by ABA bound phenolic extract $(92,22 \%)$, EBA-free phenolic extract $(85,04 \%)$ and EBA-free phenolic extract $(77,51 \%)$.

Keywords: Characterization, antioxidant, dietary fiber, avocado seed powder

\section{PENDAHULUAN}

Alpukat merupakan tanaman yang dapat tumbuh di daerah tropis seperti Indonesia. Berdasarkan data Direktorat Jenderal Hortikultura (2015) produksi buah alpukat di Indoensia sebanyak kurang lebih 3 juta ton/tahun. Di Provinsi Sulawesi Utara produksi buah alpukat pada tahun 2019 sebanyak 4.017 ton (BPS, 2019). Pada umumnya bagian buah alpukat yang dimanfaatkan yaitu daging buah sedangkan bagian lainnya dibuang dan menjadi limbah seperti bagian kulit dan biji. Limbah biji alpukat mempunyai kandungan lignoselulosa yang terdiri atas selulosa $(16,36 \%)$, hemiselulosa $(34,15 \%)$ dan lignin (15,25\%) (Diana dkk., 2018). Selulosa, hemiselulosa dan lignin disebut sebagai serat pangan dan merupakan komponen yang tidak dapat dihancurkan oleh enzim-enzim 
pencernaan dan bakteri di dalam usus (Daldiyono dkk., 1990). Selain mempunyai kandungan serat pangan, beberapa penelitian melaporkan bahwa biji alpukat juga mempunyai kandungan fitokimia seperti fenolik, tanin dan flavonoid yang memiliki aktivitas antioksidan (Ge dkk., 2017; Feliana dkk., 2018; Rivai dkk., 2019). Antioksidan adalah senyawa yang diperlukan oleh manusia untuk menangkal radikal bebas di dalam tubuh. Serat pangan dan antioksidan merupakan dua jenis komponen yang sangat bermanfaat dalam meningkatkan aktivitas kesehatan dan mampu mencegah berbagai penyakit (Suryanto, 2018).

Sifat fungsional tepung antioksidan serat pangan berubah dengan adanya perubahan pada struktur dan karakteristik permukaan akibat perlakuan pengurangan ukuran partikel (Wang dkk., 2012). Mikronisasi merupakan teknik yang ekonomis dan efektif untuk membuat partikel sangat halus. Perlakuan mikronisasi dari tepung serat pangan bisa meningkatkan kelarutan, kapasitas penyerapan air dan kapasitas penyerapan minyak (Raghavendra dkk., 2004). Penggilingan sangat halus juga dapat meningkatkan ekstraksi fenolat dari tepung serat pangan tidak larut dan meningkatkan aktivitas antioksidan dari tepung yang dihasilkan (Tao dkk., 2014).

Salah satu cara untuk memperoleh komponen bioaktif adalah dengan cara ekstraksi. Metode ekstraksi salah satunya adalah dengan teknik ultrasound-assisted extraction (UAE). UAE merupakan metode ekstraksi yang memanfaatkan gelombang ultrasonik untuk memecah dinding sel tanaman dan melepaskan isi sel ke media ekstraksi (Toma dkk., 2001). UAE telah terbukti meningkatkan efisiensi dan waktu ekstraksi. Ekstraksi kulit melinjo merah menggunakan gelombang ultrasonik dengan waktu 30 menit memberikan hasil yang terbaik dengan fenolik, flavonoid, tanin dan aktivitas antioksidan tertinggi (Rujiyanti et al., 2020). Selain itu, gelombang ultrasonik juga telah dimanfaatkan untuk delignifikasi terhadap lignoselulosa (Sasongko \& Gotama, 2019). Tujuan penelitian ini adalah untuk mengkarakterisasi dan menentukan aktivitas antioksidan serat pangan dari tepung biji alpukat yang diekstraksi menggunakan gelombang ultrasonik dengan pelarut etanol dan aquades.

\section{BAHAN DAN METODE}

Bahan yang digunakan yaitu biji alpukat yang diperoleh dari rumah makan di Kota Manado. Bahan-bahan kimia yang digunakan adalah etanol, aseton, reagen FolinCiocalteu, natrium karbonat, natrium nitrit, asam sulfanilat, N-(1Naphthyl)ethylenediamine, natrium hidroksida, asam klorida, asam sulfat diperoleh dari Merck (Damstadt, Germany), sedangkan 1,1-difenil-2pikrilhidrazil, $\alpha$-amilase dan amiloglukosidase diperoleh dari Sigma-Aldrich.

\section{Preparasi sampel}

Biji alpukat yang telah dikumpulkan, dicuci dengan air bersih dan dipotong-potong kecil lalu direbus selama 1 jam setelah itu dikeringkan dengan menggunakan oven pada suhu $50-60{ }^{\circ} \mathrm{C}$. Setelah itu, sampel dihancurkan dengan blender dan diayak menggunakan ayakan 30 mesh hingga menjadi serbuk kasar. Sampel biji alpukat yang lolos dari ayakan kemudian dihaluskan menggunakan alat milling (Fomac tipe FCT-Z200 tegangan $220 \mathrm{~V}$ daya $1 \mathrm{KW}$ frekuensi $50-60 \mathrm{~Hz}$ kecepatan putar $28.000 \mathrm{rpm})$ selama 2 menit. Hasil milling dalam bentuk tepung kemudian diayak menggunakan ayakan 200 mesh $(74 \mu \mathrm{m})$. Tepung halus selanjutnya disimpan dalam wadah kedap udara sebelum dilakukan ekstraksi dan analisis.

\section{Ekstraksi}

Tepung biji alpukat ukuran 200 mesh diekstraksi menggunakan teknik ekstraksi sonikasi dengan pelarut etanol $80 \%$ dan akuades. Masing-masing sebanyak $5 \mathrm{~g}$ tepung biji alpukat dimasukkan ke dalam gelas piala dan ditambahkan pelarut kemudian disonikasi selama 3 jam, setelah disonikasi sampel disaring sehingga diperoleh filtrat dan residu. Residu kemudian keringkan dengan oven pada suhu 50-60 ${ }^{\circ} \mathrm{C}$. Residu yang telah kering selanjutnya di milling sehingga diperoleh tepung biji alpukat yang selanjutnya dianalisis.

\section{Karakterisasi fisik}

Tepung biji alpukat dikarakterisasi secara fisik dengan spektrofotometer FTIR (Shimadzu) untuk mengetahui gugus fungsi. 


\section{Karakterisasi kimia}

Komposisi kimia tepung serat pangan biji alpukat meliputi uji kadar air, uji kadar abu, uji kadar protein, uji kadar lemak yang ditentukan dengan metode Sudarmadji (1997), sedangkan kadar karbohidrat ditentukan dengan metode by difference (SNI 01-28911992). Penentuan kandungan serat pangan menggunakan metode AOAC (1995). Semua parameter/komponen uji dilakukan 2 kali pengulangan.

\section{Penentuan kadar hemiselulosa, selulosa dan lignin}

Penentuan kadar hemiselulosa, selulosa, lignin tepung biji alpukat dilakukan dengan metode Chesson (1978) dan Datta (1981). Tepung halus biji alpukat ditimbang sebanyak 2 g kemudian dimasukkan ke dalam gelas kimia, ditambah aquades sebanyak 150 $\mathrm{mL}$ dan dipanaskan pada penangas air dengan suhu $100{ }^{\circ} \mathrm{C}$ selama $2 \mathrm{jam}$. Sampel yang sudah berbentuk bubur disaring kemudian dicuci dengan akuades sampai volume filtrat tepat $300 \mathrm{~mL}$. Residu dikeringkan dalam oven dengan suhu $105{ }^{\circ} \mathrm{C}$ sampai mencapai berat konstan. Residu yang sudah kering dimasukkan dalam labu Erlenmeyer $250 \mathrm{~mL}$, kemudian ditambah $150 \mathrm{~mL} \mathrm{H} \mathrm{SO}_{4} 1 \mathrm{~N}$ dan direfluks diatas penangas air pada suhu $100{ }^{\circ} \mathrm{C}$ selama 1 jam. Selanjutnya larutan disaring dan residu dicuci dengan aquades sampai volume filtrat mencapai $500 \mathrm{~mL}$ (netral). Residu dikeringkan dan ditimbang. Residu kering dimasukkan lagi ke dalam Erlenmeyer $250 \mathrm{~mL}$ ditambah $10 \mathrm{~mL}$ $\mathrm{H}_{2} \mathrm{SO}_{4} 72 \%$ dan didiamkan selama 4 jam pada suhu kamar, kemudian ditambah $150 \mathrm{~mL}$ $\mathrm{H}_{2} \mathrm{SO}_{4} 1 \mathrm{~N}$ dan direfluks pada pendingin balik pada suhu $100{ }^{\circ} \mathrm{C}$ selama 1 jam. Selanjutnya larutan disaring dan dicuci dengan air panas sampai netral (volume filtrat mencapai 400 $\mathrm{mL}$ ). Residu dikeringkan dan ditimbang dan selanjutnya diabukan dan ditimbang.

kadar hemiselulosa $=\frac{\mathrm{b}-\mathrm{c}}{\mathrm{a}} \times 100 \% \mathrm{~b} / \mathrm{b}$

kadar selulosa $=\frac{\mathrm{c}-\mathrm{d}}{\mathrm{a}} \times 100 \% \mathrm{~b} / \mathrm{b}$

kadar lignin $=\frac{\mathrm{d}-\mathrm{e}}{\mathrm{a}} \times 100 \% \mathrm{~b} / \mathrm{b}$

Keterangan: berat kering bahan (a), berat kering setelah diekstraksi dengan aquades (b), fraksi yang larut dalam $\mathrm{H}_{2} \mathrm{SO}_{4} 1 \mathrm{~N}$ (c), fraksi yang larut dalam $\mathrm{H}_{2} \mathrm{SO}_{4} 72 \%$ (d), kadar abu bahan (e).

\section{Ekstraksi fenolik bebas dan fenolik terikat}

Sebanyak $4 \mathrm{~g}$ tepung biji alpukat diekstraksi menggunakan teknik ekstraksi sonikasi dengan pelarut etanol $80 \%$ selama 30 menit. Setelah itu, disaring menggunakan kertas saring sehingga diperoleh filtrat dan residu. Filtrat kemudian dievaporasi pada suhu $50{ }^{\circ} \mathrm{C}$. Ekstrak pekat yang diperoleh ditimbang dan disimpan sebagai ekstrak fenolik bebas. Setelah ekstraksi fenolik bebas, $3 \mathrm{~g}$ residu dari fenolik bebas dihidrolisis dengan $60 \mathrm{~mL} \mathrm{NaOH}$ $2 \mathrm{M}$, diaduk dan didiamkan pada suhu kamar selama 2 jam. Selanjutnya, campuran dinetralkan dengan $\mathrm{HCl} 6 \mathrm{M}$ sampai $\mathrm{pH} 6$ dan diekstraksi dengan etil asetat sampai bening. Fraksi etil asetat dievaporasi pada suhu $40{ }^{\circ} \mathrm{C}$ dan dikeringkan dalam oven sehingga diperoleh ekstrak pekat. Ekstrak yang diperoleh ditimbang dan disimpan sebelum dianalisis kandungan total fenolik, kapasitas penangkal radikal bebas dan kapasitas penangkal nitrit.

\section{Penentuan kandungan total fenolik}

Kandungan total fenolik ditentukan menggunakan metode Jeong dkk. (2004). Sebanyak $0,1 \mathrm{~mL}$ masing-masing ekstrak 1000 $\mu \mathrm{g} / \mathrm{mL}$ dimasukkan ke dalam tabung reaksi, lalu ditambahkan $0,1 \mathrm{~mL}$ reagen Folin Ciocalteu $50 \%$ dalam tabung reaksi dan kemudian campuran divortex selama 3 menit. Setelah interval waktu 3 menit, ditambahkan 2 mL larutan $\mathrm{Na}_{2} \mathrm{CO}_{3} 2 \%$, kemudian campuran diinkubasi dalam ruang gelap selama 30 menit. Selanjutnya dibaca absorbansinya pada $\lambda 750$ $\mathrm{nm}$ dengan menggunakan spektrofotometer UV-Vis. Hasilnya dinyatakan sebagai ekuivalen asam galat dalam $\mu \mathrm{g} / \mathrm{mL}$ ekstrak.

\section{Penentuan aktivitas penangkal radikal bebas}

Penentuan aktivitas penangkal radikal bebas tepung biji alpukat ditentukan dengan metode Burda \& Oleszeck (2001). Sebanyak $0,5 \mathrm{~mL}$ masing-masing ekstrak ditambahkan dengan 1,5 $\mathrm{mL}$ larutan DPPH dan divortex selama 2 menit. Berubahnya warna larutan dari ungu ke kuning menunjukkan efisiensi penangkal radikal bebas. Selanjutnya pada 5 
menit terakhir menjelang 30 menit inkubasi, absorbansinya diukur pada panjang gelombang $517 \mathrm{~nm}$ dengan menggunakan spektrofotometer UV-Vis. Aktivitas penangkal radikal bebas (APRB) dihitung sebagai persentase berkurangnya warna DPPH dengan menggunakan persamaan:

$$
\text { APRB }=\left(1-\frac{\text { absorbansi sampel }}{\text { absorbansi kontrol }}\right) \times 100 \%
$$

\section{Penentuan kapasitas penangkal nitrit}

Kapasitas penangkal nitrit ditentukan menggunakan metode Zhang dkk. (2009). Sebanyak $2 \mathrm{~mL}$ natrium nitrit $5 \mathrm{mg} / \mathrm{L}$ dicampur dengan $3 \mathrm{~mL}$ ekstrak dalam labu $25 \mathrm{~mL}$ pada suhu kamar selama 30 menit. Larutan campuran dicampur dengan $1 \mathrm{~mL}$ asam sulfanilat $0,4 \%$ distirer selama 5 menit diikuti penambahan $\quad 0,5 \quad \mathrm{~mL} \quad \mathrm{~N}-(1-$ Naphthyl)ethylenediamine $0,1 \%$ dan volume disesuaikan menjadi $25 \mathrm{~mL}$ dengan aquades. Larutan didiamkan selama 15 menit dan diukur absorbansi menggunakan spektrofotometer UV-Vis pada $\lambda 538 \mathrm{~nm}$. Kapasitas penangkal nitrit (\%) dihitung menggunakan rumus:

$$
\operatorname{KPN}(\%)=\left(\frac{A_{0}-\left(A_{1}-A_{2}\right)}{A_{0}}\right) \times 100 \%
$$

Keterangan: $\mathrm{A}_{0}=$ absorbansi $\mathrm{NaNO}_{2} ; \mathrm{A}_{1}=$ absorbansi $\mathrm{NaNO}_{2}$ dan ekstrak; $\mathrm{A}_{2}=$ absorbansi ekstrak.

\section{HASIL DAN PEMBAHASAN}

\section{Rendemen tepung biji alpukat}

Sampel yang digunakan dalam penelitian ini adalah biji alpukat. Biji alpukat yang telah direbus dipotong-potong kecil dan dikeringkan dengan oven selama 3 hari pada suhu $50-60{ }^{\circ} \mathrm{C}$. Setelah itu, biji alpukat di mikronisasi sehingga menjadi tepung yang selanjutnya di ekstraksi secara sonikasi. Tujuannya adanya untuk menghilangkan komponen pengotor yang terdapat dalam tepung biji alpukat dan meningkatkan kandungan serat pangan. Berdasarkan penelitian ini nilai rendemen tepung biji alpukat yang disonikasi dengan pelarut etanol dan aquades berturut-turut adalah $88,84 \%$ dan $86,49 \%$. Dari data tersebut dapat disimpulkan bahwa pelarut etanol menarik lebih banyak komponen dari tepung yang diekstraksi dibandingkan pelarut aquades. Penggunaan pelarut etanol karena merupakan pelarut universal dimana dapat melarutkan hampir semua senyawa organik yang ada pada sampel, baik senyawa polar maupun non polar (Noviyanti, 2016).

\section{Komposisi kimia tepung biji alpukat}

Hasil analisis proksimat tepung biji alpukat merupakan hasil rata-rata dari dua kali pengulangan yang ditunjukkan pada Tabel 1 . Analisis proksimat meliputi analisis kadar air, kadar abu, kadar protein, kadar lemak, dan kadar karbohidrat.

Tabel 1. Hasil analisis komposisi kimia tepung biji alpukat

\begin{tabular}{lcl}
\hline $\begin{array}{c}\text { Jenis } \\
\text { Komposisi }\end{array}$ & EBA & ABA \\
\hline Air & $7,94 \pm 0,14^{\mathrm{a}}$ & $8,84 \pm 0,73^{\mathrm{a}}$ \\
Abu & $1,87 \pm 0,07^{\mathrm{a}}$ & $1,64 \pm 0,12^{\mathrm{a}}$ \\
Protein & $5,32 \pm 0,50^{\mathrm{a}}$ & $5,20 \pm 0,08^{\mathrm{a}}$ \\
Lemak & $0,47 \pm 0,15^{\mathrm{a}}$ & $0,79 \pm 0,21^{\mathrm{a}}$ \\
Karbohidrat & $84,39 \pm 0,02^{\mathrm{a}}$ & $83,53 \pm 0,28^{\mathrm{a}}$ \\
SP Terlarut & $0,24 \pm 0,02^{\mathrm{a}}$ & $0,37 \pm 0,02^{\mathrm{b}}$ \\
SP Tak Larut & $18,40 \pm 0,02^{\mathrm{a}}$ & $17,79 \pm 0,02^{\mathrm{b}}$ \\
SP Total & $18,64 \pm 0,02^{\mathrm{a}}$ & $18,16 \pm 0,02^{\mathrm{b}}$ \\
\hline
\end{tabular}

Keterangan: Tepung biji alpukat yang diekstraksi dengan etanol (EBA), tepung biji alpukat yang diekstraksi dengan akuades (ABA), serat pangan (SP).

Berdasarkan Tabel 1 kadar air yang terdapat pada EBA $7,94 \%$ sedangkan pada ABA 8,84\%. Hasil uji statistik menunjukkan adanya perlakuan dengan perbedaan pelarut tidak berpengaruh nyata $(p>0,05)$ terhadap kadar air. Hal ini mungkin disebabkan oleh waktu dan suhu pengeringan yang digunakan sama serta menggunakan pelarut yang keduanya bersifat polar. Menurut Riansyah dkk. (2013) bahwa setiap perbedaan suhu dan 
waktu pengeringan yang diberikan akan memberikan pengaruh yang sangat nyata terhadap perpindahan air pada bahan.

Kadar abu pada EBA 1,87\% sedangkan pada ABA 1,64\%. Kadar abu pada penelitian ini lebih rendah dibandingkan kadar abu pada penelitian Egbuonu dkk. (2018) sebesar 1,97\%. Tinggi rendahnya kadar abu yang terkandung dalam suatu bahan dapat dihubungkan dengan jumlah unsur mineral yang terkandung dalam bahan tersebut (Ratana-arporn \& Chirapart).

Kadar protein EBA 5,32\% sedangkan pada ABA 5,20\%. Hasil uji statistik menunjukkan adanya perlakuan dengan perbedaan pelarut tidak berpengaruh nyata $(\mathrm{p}>0,05)$ terhadap kadar protein. Namun kadar protein pada penelitian ini lebih tinggi bila dibandingkan dengan kadar protein pada penelitian Barbosa-Martin dkk. (2016) yaitu sebesar 4,98\%. Pebedaan ini diduga karena suhu dan lama pengeringan yang digunakan. Menurut Yuniarti dkk. (2013), bahwa pemanasan yang terlalu lama dengan suhu yang tinggi akan menyebabkan protein terdenaturasi.

Hasil uji statistik menunjukkan kadar lemak pada EBA dan ABA tidak berbeda nyata $(p>0,05)$. Hal ini diduga dipengaruhi oleh kadar air pada masing-masing sampel. Dimana kandungan air paling kecil terdapat pada EBA. Almatsier (2009), menyatakan bahwa kandungan lemak berbanding lurus dengan kadar air yang terdapat dalam suatu bahan.
Kandungan serat pangan total pada EBA $(18,64 \%)$ yang terdiri atas serat pangan tak larut $(18,40 \%)$ dan serat pangan larut $(0,24 \%)$ sedangkan pada ABA kandungan serat pangan total $(18,16 \%)$ yang terdiri atas serat pangan tak larut $(17,79 \%)$ dan serat pangan larut $(0,37 \%)$. Perbedaan kandungan serat pangan diduga karena adanya perlakuan ekstraksi menggunakan gelombang ultrasonik. Pradana dkk. (2017) menyatakan bahwa gelombang ultrasonik pada ekstraksi padat cair membentuk gelembung kavitasi yang memiliki kemampuan dalam memecah struktur matriks dari dinding sel tanaman termasuk polimer dari serat seperti lignoselulosa.

\section{Kandungan hemiselulosa, selulosa dan lignin}

Berdasarkan Tabel 2 diketahui kandung hemiselulosa, selulosa dan lignin pada EBA $42,69 \% ; 4,35 \% ; 15,14 \%$ dan pada ABA $37,71 \% ; 5,47 \% ; 20,08 \%$. Dari data tersebut menunjukkan bahwa dengan adanya perlakuan ekstraksi menggunakan gelombang ultrasonik meningkatkan kandungan hemiselulosa, selulosa dan menurunkan kandungan lignin. Tujuan dari ekstraksi secara sonikasi yang memanfaatkan gelombang ultrasonik adalah untuk membuka struktur lignoselulosa agar selulosa menjadi lebih mudah diakses oleh enzim yang memecah polimer polisakarida menjadi monomer gula sehingga kadar selulosa akan meningkat sedangkan kadar lignin akan semakin turun (Mosier dkk., 2005).

Tabel 2. Kandungan hemiselulosa, selulosa dan lignin

\begin{tabular}{lll}
\hline \multirow{2}{*}{ Kandungan } & \multicolumn{2}{c}{ Sampel } \\
\cline { 2 - 3 } & \multicolumn{1}{c}{ EBA } & \multicolumn{1}{c}{ ABA } \\
\hline Hemiselulosa & $42,69 \pm 0,17^{\mathrm{a}}$ & $37,71 \pm 0,17^{\mathrm{b}}$ \\
Selulosa & $4,35 \pm 0,03^{\mathrm{a}}$ & $5,47 \pm 0,04^{\mathrm{b}}$ \\
Lignin & $15,14 \pm 0,08^{\mathrm{a}}$ & $20,08 \pm 0.04^{\mathrm{b}}$ \\
\hline
\end{tabular}

Singkatan seperti terdapat pada Tabel 1

\section{Hasil analisis Fourier Transform Infra Red (FTIR)}

Berdasarkan Gambar 1 spektrum dari EBA dan ABA muncul pada bilangan gelombang $3402,43 \mathrm{~cm}^{-1}$ yang mana pada daerah serapan 3550-3200 $\mathrm{cm}^{-1}$ menunjukkan getaran $\mathrm{O}-\mathrm{H}$ yang dikaitkan dengan peregangan $\mathrm{O}-\mathrm{H}$ dari gugus hidroksil terutama yang berasal dari selulosa (Milovanovic dkk., 2016). Spektrum dari EBA dan ABA juga menunjukkan serapan pada bilangan gelombang 2924,08 $\mathrm{cm}^{-1}$ yang mana daerah serapan $3000-2840 \mathrm{~cm}^{-1}$ menunjukkan vibrasi $\mathrm{C}-\mathrm{H}$ dari selulosa yang mengindikasikan kehadiran senyawa polisakarida (Abbasi dkk., 2016). Pada kedua sampel terdapat serapan pada bilangan gelombang $1442,75 \mathrm{~cm}^{-1}$ dimana menurut Shanmugarajah dkk. (2015), daerah serapan sekitar $1400 \mathrm{~cm}^{-1}$ menandakan adanya ikatan $\mathrm{CH}_{2}$ yang berdeformasi dalam selulosa. 
Hal ini sesuai dengan spektrum pada MKS yang memiliki serapan pada $1427,32 \mathrm{~cm}^{-1}$. Pada area bilangan gelombang $1420-1450 \mathrm{~cm}^{-1}$ disebut juga sebagai pita kristalinitas (Ciolacu dkk., 2011). Selain itu, hemiselulosa memiliki gugus-gugus fungsi yang hampir sama dengan selulosa

(Hisyam,



Gambar 1. Spektrum FT-IR dari ekstrak dengan etanol (EBA) dan ekstrak dengan akuades (ABA),

Pada kedua sampel terdapat serapan pada bilangan gelombang 1026,13 $\mathrm{cm}^{-1}$. Menurut Peng dkk. (2010), getaran yang menonjol disekitar $1044 \mathrm{~cm}^{-1}$ merupakan peregangan $\mathrm{C}-\mathrm{O}, \mathrm{C}-\mathrm{C}$ atau pembengkokan $\mathrm{C}-\mathrm{OH}$ dalam xilan. Xilan merupakan komponen terbesar penyusun hemiselulosa dinding sel tanaman dan termasuk dalam jenis polisakarida paling berlimpah kedua setelah selulosa (Nareswari, 2007). Spektrum dari kedua sampel juga menunjukkan adanya serapan pada bilangan gelombang $1249,87 \mathrm{~cm}^{-1}$ dimana dilaporkan oleh Reddy dkk. (2005) bahwa bilangan gelombang pada daerah serapan antara 1300-1200 $\mathrm{cm}^{-1}$ yang mengindikasikan vibrasi kerangka aromatik yang berasal dari lignin. Selain itu, terdapat serapan pada bilangan gelombang $1026,13 \mathrm{~cm}^{-1}$ dimana serapan yang menonjol di sekitar 1020-
$1035 \mathrm{~cm}^{-1}$ berkaitan dengan $\mathrm{C}-\mathrm{O}-\mathrm{C}$ (ikatan eter) dari ikatan glikosidik (Liu \& Bai, 2005).

\section{Ekstraksi dan kandungan fenolik}

Ekstraksi merupakan proses pemisahan suatu komponen dari campurannya dengan menggunakan pelarut yang sesuai. Metode ekstraksi yang digunakan dalam penelitian ini adalah sonikasi dan hidrolisis dengan asam dan basa. Ekstraksi EBA dan ABA dengan pelarut etanol digunakan untuk mendapatkan ekstrak fenolik bebas sedangkan residu hasil ekstraksi fenolik bebas dihidrolisis dengan asam dan basa untuk mendapatkan ekstrak fenolik terikat. Tabel 3 menunjukkan rendemen ekstraksi dan kandungan total fenolik dari tepung biji alpukat.

Tabel 3. Rendemen ekstraksi dan kandungan total fenolik dari tepung biji alpukat

\begin{tabular}{ccc}
\hline Sampel & $\begin{array}{c}\text { Rendemen } \\
(\%)\end{array}$ & $\begin{array}{c}\text { Kandungan fenolik } \\
(\mu \mathrm{g} / \mathrm{mL})\end{array}$ \\
\hline EFT EBA & 79,98 & $100,90 \pm 0,58^{\mathrm{a}}$ \\
EFB EBA & 87,35 & $135,25 \pm 0,46^{\mathrm{b}}$ \\
\hline EFT ABA & 78,76 & $80,66 \pm 0,23^{\mathrm{c}}$ \\
EFB ABA & 79,32 & $109,18 \pm 0,23^{\mathrm{d}}$ \\
\hline
\end{tabular}

Singkatan seperti terdapat pada Tabel 1 
Berdasarkan Tabel 3 diketahui rendemen ekstrak fenolik terikat pada EBA dan ABA lebih tinggi dibandingkan ekstrak fenolik bebasnya. Tinggi nilai rendemen ekstrak fenolik terikat menunjukkan bahwa masih terdapat kandungan fenolik di dalam residu hasil ekstraksi sonikasi yang tidak terekstrasi. Hal ini kemungkinan disebabkan oleh adanya ikatan glikosidik yang menyebabkan senyawa fenolik tidak mudah diekstrasi dengan pelarut sedangkan ekstraksi menggunakan asam dan basa dapat memuuts ikatan antara senyawa fenolik dengan karbohidrat sehingga mempunyai nilai rendemen yang lebih tinggi. Senyawa fenolik merupakan zat pada tumbuhan yang memiliki gugus aromatik dengan satu atau lebih gugus $\mathrm{OH}$. Penelitian pada ini, kandungan total fenolik ditentukan secara spektrofotometri dengan reagen Folin-Ciocalteu. Metode ini memiliki banyak keuntungan yaitu sederhana, dapat diulang, hasil yang akurat dan telah digunakan secara luas (Fu dkk., 2011). Pada Tabel 3 diketahui kandungan total fenolik dari tepung biji alpukat paling tinggi terdapat pada ekstrak fenolik terikat EBA $(135,25 \mu \mathrm{g} / \mathrm{mL})$, diikuti ekstrak fenolik terikat ABA $(109,18 \mu \mathrm{g} / \mathrm{mL})$, ekstrak fenolik bebas EBA $(100,90 \mu \mathrm{g} / \mathrm{mL})$ dan terendah pada ekstrak fenolik ABA $(80,66 \mu \mathrm{g} / \mathrm{mL})$. Hasil uji statistik menunjukkan adanya perbedaan dari masing-masing ekstrak $(p<0,05)$ terhadap kandungan fenolik. Dari data tersebut menunjukkan bahwa ekstrak fenolik terikat memiliki kandungan fenolik yang lebih tinggi dari ekstrak fenolik bebas. Hal tersebut diduga bahwa pada sampel dari sisa penyaringan selama diekstraksi menggunakan basa masih mengandung bahan aktif terutama senyawa fenolik yang terkandung dalam residu tersebut. Menurut Parra dkk. (2007) senyawa fenolik terikat yang tinggi mengindikasikan residu hasil ekstrak fenolik bebas masih banyak mengandung senyawa fenolik.

\section{Aktivitas penangkal radikal bebas}

Aktivitas penangkal radikal bebas dari tepung biji alpukat ditentukan dengan metode serapan radikal bebas 1,1-difenil-2pikrilhidrazil (DPPH). Radikal DPPH adalah radikal bebas stabil yang dapat larut dalam metanol atau etanol serta menunjukkan karakteristik pada panjang gelombang 515-517 nm (Suryanto dkk., 2017). Absorbansi pada $517 \mathrm{~nm}$ menurun sebagai reaksi antara molekul antioksidan dan radikal DPPH. Hal ini ditunjukkan dengan perubahan warna dari ungu menjadi kuning (Suryanto \& Wehantouw, 2009). Hasil pengujian kemampuan penangkal radikal bebas DPPH dari ekstrak fenolik EBA dan ABA ditunjukkan pada Tabel 4.

Tabel 4. Aktivitas penangkal radikal bebas ekstrak EBA dan ABA

\begin{tabular}{ccc}
\hline Sampel & Jenis ekstrak & $\begin{array}{c}\text { Aktivitas penangkal radikal bebas } \\
(\%)\end{array}$ \\
\hline \multirow{2}{*}{ EBA } & EFB & $85,04 \pm 0,56^{\mathrm{a}}$ \\
& EFT & $95,93 \pm 0,07^{\mathrm{b}}$ \\
\hline \multirow{2}{*}{ ABA } & EFB & $77,51 \pm 0,14^{\mathrm{c}}$ \\
& EFT & $92,22 \pm 0,21^{\mathrm{d}}$ \\
\hline
\end{tabular}

Hasil analisis penangkal radikal bebas dari Tabel 9 menunjukkan aktivitas penangkal radikal bebas DPPH melebihi 50\%, hal ini berarti bahwa ekstrak fenolik bebas dan fenolik terikat dapat menghambat radikal bebas seperti fungsi antioksidan primer. Antioksidan primer dapat menangkal radikal bebas melalui pemberian hidrogen kepada radikal bebas DPPH yang berwarna ungu dan akan berubah menjadi non radikal yang berwarna kuning. Semakin berkurangnya warna ungu menunjukkan bahwa kemampuan antioksidan tersebut untuk menangkal radikal bebas DPPH semakin kuat (Suryanto, 2018). Hasil analisis penangkal radikal bebas pada Tabel 4 terhadap dua jenis ekstrak EBA dan ABA menunjukkan bahwa persentase penangkal radikal bebas pada ekstrak fenolik terikat pada masing-masing sampel lebih tinggi dibandingkan ekstrak fenolik bebas. Hal ini mungkin disebabkan residu dari ekstrak fenolik bebas yang dihidrolisis dengan basa dan asam masih mengandung fitokimia antioksidan. Yang dkk. (2018) melaporkan bahwa proses hidrolisis asam-basa dari residu hasil ekstrak fenolik bebas dan diekstraksi dengan etil asetat dapat meningkatkan kandungan total fenolik dan aktivitas antioksidan yang terkandung dalam residu tersebut. 


\section{Kapasitas penangkal nitrit}

Dalam usus atau lambung manusia nitrit dapat bereaksi dengan amina sekunder dan membentuk senyawa nitrosamin yang bersifat toksik. Pembentukan senyawa nitrosamin dapat dihambat oleh senyawa fenolik. Metode spektrofotometri sinar tampak dalam penetapan kadar nitrit adalah berdasarkan reaksi kolorimetri uji Griess dimana nitrit mengalami reaksi diazotasi dengan asam sulfanilat dan $\mathrm{N}$ (1-Naftil)-etilendiamin dihidroklorida yang akan menghasilkan senyawa azo berwarna ungu kemerahan yang diukur secara spektrofotometri sinar tampak pada panjang gelombang $540 \mathrm{~nm}$ (Svehla, 1979). Kapasitas penangkal nitrit ekstrak EBA dan ABA ditunjukkan pada Tabel 5.

Tabel 5. Aktivitas penangkal radikal bebas ekstrak EBA dan ABA

\begin{tabular}{ccc}
\hline \multirow{2}{*}{ Sampel } & Jenis ekstrak & $\begin{array}{c}\text { Kapasitas penangkal nitrit } \\
(\%)\end{array}$ \\
\cline { 3 - 3 } \multirow{2}{*}{ EBA } & EFB & $51,28 \pm 0,32^{\mathrm{a}}$ \\
& EFT & $73,76 \pm 0,21^{\mathrm{b}}$ \\
\hline \multirow{2}{*}{ ABA } & EFB & $42,68 \pm 0,43^{\mathrm{c}}$ \\
& EFT & $57,84 \pm 0,43^{\mathrm{d}}$ \\
\hline
\end{tabular}

Berdasarkan hasil analisis statistik pada Tabel 5. menunjukkan bahwa kapasitas penangkal nitrit tertinggi terdapat pada ekstrak fenolik terikat dari masing-masing sampel yaitu EBA $(73,76 \%)$ dan ABA $(57,84 \%)$ dan TPBA (41,58\%). Sedangkan untuk ekstrak fenolik bebas lebih rendah dari setiap sampel dimana EBA (51,28\%), ABA (42,68\%), dan TPBA (35,52\%). Hal ini kemungkinan dipengaruhi oleh kandungan senyawa fenolik pada masing-masing ekstrak. Hal ini sesuai dengan beberapa penelitian yang menunjukkan adanya hubungan yang kuat antara kandungan total fenolik dengan kapasitas penangkal nitrit dari berbagai ekstrak tanaman (Nova dkk., 2020; Dareda dkk., 2020; Karepu dkk., 2020).

\section{KESIMPULAN}

Karakterisasi tepung biji alpukat EBA dan ABA dengan Fourier Transform Infra Red (FTIR) menunjukkan tidak adanya perubahan mendasar pada komponen utama setelah proses penggilingan dan ekstraksi secara sonikasi. Hasil karakterisasi secara kimia menunjukkan kadar abu, protein, karbohidrat, serat pangan tak larut, serat pangan total dan hemiselulosa tertinggi terdapat pada EBA sedangkan kadar air, lemak, serat pangan larut, selulosa dan lignin tertinggi terdapat pada ABA. Aktivitas antioksidan menunjukkan bahwa ekstrak fenolik terikat EBA dan ABA lebih tinggi dibandingkan dengan ekstrak fenolik bebas EBA dan ABA.

\section{DAFTAR PUSTAKA}

Abbasi, M.A., Islam, M., Rehman, A.U., Rasool, S., Rubab, K., Hussain, G., Ahmad, I., Ahsraf, M., Shadid, M. \& Sha, S.A.A. 2016. Synthesis, characterization, antibacterial, $\alpha$ glucosidase inhibition and hemalytic studies on some new N-(2,3Dimethylphenyl) benzene sulfonamide derivatives. Tropical Journal of Phamarceutical Research. 15(3), 591598.

AOAC. 1995. Official Methods of Analysis of Association of Official Analytical Chemist. AOAC International, Washington.

Badan Pusat Statistik Sulawesi Utara. 2019. Statistik Hortikultura Sulawesi Utara 2019. BPS Provinsi Sulawesi Utara, Manado.

Burda, S. \& Oleszek, W. 2001. Antioxidant and antiradical activities of flavonoids. Journal of Agriculture and Food Chemistry. 49(6), 27742779.

Chesson, A. 1981. Effects of sodium hydroxide on cereal straws in relation to the enhanced degradation of structural polysaccharides by rumen microorganisms. Journal Science Food Agriculture. 32(8), 745-758.

Ciolacu, D., Ciolacu, F. \& Popa, V.I. 2011. Amorphous cellulose structure and characterization. Cellulose Chemistry and Technology. 45(1), 13-21. 
Daldiyono, Ismail, A., Rani, A.A., Manan, C. \& Sumadibrata, R. 1990. Kanker Kolon dan Peram Diet Tinggi Serat: Kejadian di Negara Barat. Gizi Indonesia. 15(1), 73-75.

Dareda, C.T., Suryanto, E. \& Momuat, L.I. 2020. Karakterisasi dan aktivitas antioksidan serat pangan dari daging buah pala (Myristica fragrans Houtt). Chemistry Progress. 13(1), 48-55.

Datta, R. 1981. Acidogenic fermentation of lignocelluloses acid yield and convertion of componens. Biotechnology and Bioengineering. 23(9), 2167-2170.

Diana, Y., Carlos, M. \& Edith, C. 2018. Effect of maturity state of avocado (Persea americana Mill. cv. Hass) on seed characteristics. Advance Journal of Food Science and Technology. 16(5), 301-306.

Feliana, K., Mursiti, S. \& Harjono. 2018. Isolasi dan elusidasi senyawa flavonoid dari biji alpukat (Persea americana Mill.). Indonesian Journal of Chemical Science. 7(2), 153-159.

Ge, Y., Si, X., Cao, J., Zhou, Z., Wang, W. \& Ma, W. 2017. Morphological characteristics, nutrional quality, and bioactive constituents in fruit of two avocado (Persea americana) varieties from Hainan province, China. Journal of Agricultural Science. 9(2), 8-17.

Jeong, S.M., Kim, S.Y., Kim, D.R., Jo, S.C., Nam, K.C., Ahn, D.U. \& Lee, S.C. 2004. Effect of heat treatment on the antioxidant activity of extracts from citrus peels. Journal of Agricultural and Food Chemistry. 52(11), 33893393.

Karepu, M.G., Suryanto, E. \& Momuat, L.I. 2020. Komposisi kimia dan aktivitas antioksidan dari paring kelapa (Cocos nucifera). Chemistry Progress. 13(1), 39-47.

Liu, C. \& Bai, R. 2005. Preparation of chitosan/cellulose acetate blend hollow fibers for absorptive performance. Journal of Membrane Science. 267(1), 68-77.

Milovanovic, S., Markovic, D., Aksentijevic, K., Stojanovic, D.B., Ivanovic, J. \& Zizovic, I. 2016. Application of cellulose acetate for controlled release of thymol. Carbohydrate Polymers. 147(2), 344-353.

Mosier, N.S., Wyman, C. \& Dale, B. 2005. Features of promising technologies for pretreatment of lignocellulosic biomass. Bioresource Technology. 96(6), 673-686.

Nova, Suryanto, E. \& Momuat, L.I. 2020. Karakterisasi fisikokimia dan aktivitas antioksidan serat pangan dari ampas empulur sagu baruk (Arenga microcarpha B.). Chemistry Progress. 13(1), 22-30.

Peng, F., Ren, J.L., Xu, F., Bian, J., Peng, B. \& Sun, R.C. 2010. Fractional study of alkali-soluble hemicellulose obtained by graded ethanol precipitation from sugar cane bagasse. Journal of Agricultural and Food Chemistry. 58(3), 1768-1776.

Raghavendra, S.N., Rastogi, N.K. \& Raghavarao, K.S.M.S. 2004. Dietary fiber from coconut residue: effects of different treatments and particle size on the hydration properties. European Food Research and Technology. 218(6), 536-567.

Reddy, N. \& Yang, Y. 2005. Structure and properties of high quality natural cellulose fiber from cornstalks. Polymer. 46(15), 5494-5500.

Rivai, H., Putri, Y.T. \& Rusdi, R. 2019. Qualitative and quantitative analysis of the chemical content of hexane, acetone, ethanol and water extract from avocado seeds (Persea americana Mill.). Scholars International Journal of Traditional and Complementary Medicine. 2(3), 25-31.

Rujiyanti, L.M., Kunarto, B. \& Pratiwi, E. 2020. Pengaruh lama ekstraksi kulit melinjo merah (Gnetum gnemon L.) berbantu gelombang ultrasonik terhadap yield, fenolik, flavonoid, tanin dan aktivitas antioksidan. Jurnal Teknolgi Pangan dan Hasil Pertanian. 15(1), 17-27.

Sasongko, A. \& Gotama, B. 2019. Hidrolisis limbah kulit nanas dengan asam asetat menggunakan metode ultrasoundassisted acid hydrolysis (UAAH) untuk produksi oligosakarida. Jurnal Sains Terapan. 5(2), 101-106. 
Shanmugarajah, B., Kiew, P.L., Chew, I.M.L. \& Choong, T.S.Y. 2015. Isolation of nanocrystalline cellulose (NCC) from palm oil empty friut bunch (EFB): preliminary result of ftir and dls analysis. Chemical Engineering Transactions. 45(2), 1705-1710.

Sudarmadji. 1997. Prosedur Analisa untuk Bahan Makanan dan Pertanian. Liberty, Yogyakarta.

Suryanto, E. 2018. Kimia Antioksidan. CV. Patra Media Gravindo, Bandung

Tao, B., Ye, F., Li, H., Hu, Q., Xue, S. \& Zhao, G. 2014. Phenolic profile and in vitro antioxidant capacity of insoluble dietary fiber powders from citrus (Citrus junos Sieb. ex Tanaka) pomace as affected by ultrafine grinding. Journal of Agricultural and Food Chemistry. 62(29), 7166-7173.
Toma, M., Vinatoru, M., Paniwnyk, L. \& Mason, T.J. 2001. Investigaton of the effect of ultrasound on vegetal tissue during solvent extraction. Journal Ultrasonic Sonochemistry. 8(2), 137142.

Wang, T., Sun, X., Zhou, Z. \& Chen, G. 2012. Effects of microfluidization process on physicochemical properties of wheat bran. Food Research International. 48(2), 742747.

Zhang, L., Xu, H. \& Li, S. 2009. Effects of micronization on properties of chaenomeles sinensis (Thouin) koehne fruit powder. Innovative Food Science \& Emerging Technologies. 10(4), 633637. 